\title{
Local Conditions, Global Environment and Transnational Discourses in Memory Work: The Case of Bloody Sunday (1972)
}

\author{
Brian Conway \\ Department of Sociology \\ National University of Ireland, Maynooth \\ Maynooth \\ Co. Kildare \\ Ireland
}

MEMORY STUDIES 2008 1(2): 187-209

*The definitive version is available at: http://mss.sagepub.com/current.dtl

\begin{abstract}
Within the collective memory literature, very few scholars have sought to examine commemoration through the lens of globalization theory even though it poses challenges to understandings of time and space that underpin memory studies. This article examines the local political conditions and global institutional environment influencing memory discourses. Drawing on the case of Bloody Sunday (1972), I examine the role of memory choreographers in constructing universalizing commemorative idioms and the local conditions and global setting influencing this memory work. I argue that the mid-1990s was characterised by an increasing emphasis on Bloody Sunday's globally 'chic' qualities that seemed to liquidate its earlier localized meaning and that this was achieved through drawing analogies between the Bloody Sunday experience and other global casualties of injustice and oppression. This narrative reframing of the event is explained in terms of Irish, British, European, American and global influences as well as political, economic and demographic shifts, which came together in the mid-1990s, to create a propitious environment for a global turn in Bloody Sunday memory.
\end{abstract}




\section{Introduction}

Within the collective memory literature increasing attention is given to memory politics and to the ways in which the past can be mobilized to underwrite group identity as well as a form of resistance and negotiation. This emphasis on the mobilizable potential of the past is crystallized in the concepts of 'memory work' and 'memory entrepreneurs' and a number of scholars have found these useful as a frame of reference, leading in turn to a concern about the robustness or changeability of memory over time (Jansen, 2007; Spillman, 2003; Olick and Robbins, 1998; Rappaport, 1990). One scholar who has been particularly influential in these debates is Jeffrey Olick (Olick, 1999, 2003). Olick’s recent emphasis on a processional approach to collective memory, with respect to Germany’s remembrance of 8 May 81945 focuses attention on 'social remembering as the ideological projects and practices of actors in settings' (Olick, 2003: 6) that is an ongoing, dynamic and continuing effort. He makes the interesting point that contextual changes help to account for changes in remembrance and he does not limit this to shifting political circumstances. Included in his understanding of 'context' are earlier commemorations and he suggests that earlier commemorations enable and constrain later ones.

Olick’s processional approach poses both theoretical and methodological challenges for collective memory studies. At a methodological level, it seems to call for a long-range historical analysis of commemoration. In this paper, following Olick, I identify - with reference to the commemoration of Bloody Sunday (1972) - 
different memory discourses across three historical phases and examine whether earlier commemorations constrained later ones. Theoretically it invites us to examine memory as an ongoing dynamic process rather than a static thing.

But almost all of the collective memory literature, as well as the subset of it examined using this 'processional' lens, is restricted to looking at memory in various local contexts or in global terms and it is very difficult to find any studies that engage with both. The Bloody Sunday case represents a particularly interesting case study because of the local and global dynamics of collective memory involved in it (Spillman and Conway, 2007; Conway, 2003) over the course of the last thirty-five years. I am particularly interested in the emergence of global memory discourses with respect to Bloody Sunday memory in the mid-1990s and attempting to account for this in terms of both a shifting global environment as well as a shifting local political context. In addition, I examine the extent to which memory entrepreneurs 'domesticated' global discourses for local Derry audiences and to what extent this globalizing idiom generated controversy, or not, at a local level. In focusing on the activities of memory entrepreneurs, less attention is given to public reactions - the consumption side - to this memory work that other research has drawn attention to as being significant in terms of our understanding of collective memory (see Brubaker and Feischmidt, 2002). To provide a framework for this analysis I begin by looking at how the collective memory and globalization literatures seem, on the face of it, to offer opposing understandings of societal and group identity formation. After this I move on to examine the Bloody Sunday case with special attention given to the interaction of local conditions and the global environment in shaping translocal memory discourses and commemorative strategies around this event. 


\section{Two Literatures: Collective Memory and Globalization}

The literature on collective memory is based on very strong geographical understandings of the basic co-ordinates of time and space. Paul Connerton writes in his influential text How Societies Remember, that Maurice Halbwachs did a very good job of demonstrating 'how no collective memory can exist without reference to a socially specific spatial framework' (Connerton, 1989: 37). Halbwachs himself reminds us that 'it is in society that people normally acquire their memories. It is also in society that they recall, recognize and localize their memories’ (Halbwachs, 1992: 38). Discussing religion as a social framework of memory, he makes the point that 'it is not in the present but in the past that we must look for its grounding' (Halbwachs, 1992: 178) and goes on to claim that religion exerts its influence in 'defined places and periods’ (Halbwachs, 1992: 178).

Anthony Smith's work fits squarely within this tradition and is representative of a significant body of literature that quarantines national collective identity formation within the boundaries of the nation. Arguing that group identity is 'always historically specific because it is based on shared memories and a sense of continuity between generations' (Smith, 1990: 180), Smith claims that 'global culture is essentially memoryless' (Smith, 1990: 179). Through the influence of this nation-centered work such as this then, we have come to understand memory and identity, as having strong geographical or spatial bases (Brenner, 1999) and the scholarship on globalization, seems, on the face of it, to problematize this 'territorial trap' (Brenner, 1999) because it speaks so much about the transformation in our individual and collective experiences of time and space (Levy and Sznaider, 2006). Rather than seeing people as being tied to specific times and spaces, this literature points to the porousness of these co-ordinates of human experience and to time- 
space compression. Some of this literature even goes so far as to claim, as Ó Riain points out, that we live in a post-nation society, a world characterized by the 'death of distance' and the 'end of history' (Ó Riain, 2006). In this view we left with a borderless world system, in which people, ideas, information, and goods flow easily and readily across the globe leading to the 'disembedding' or liquidation of the local (Giddens, 1991).

A particularly interesting line of globalization research, bearing upon the present paper, is world society theory put forward by neo-institutional scholars such as John Meyer and colleagues (Meyer et al, $1997^{2}$ ). The basic line of argument here is that there is a clear pattern of convergence between different national societies across a whole range of cultural and political fields including national development plans, political constitutions, educational curricula, human rights and equality policies, and so forth. According to this view, the nation is a 'babbitt' (Meyer, 2004) that appropriates global cultural scripts furnished by transnational institutions and organizations such as the World Bank, the International Monetary Fund, and the United Nations, as well as nongovernmental organizations. It is argued that nation states establish their legitimacy and credentials as 'nice', 'likeable' first-world countries in the eyes of these global political actors by following these scripts through their membership in international organizations and participation in international conferences (Meyer, 2004; Cole, 2005; Conway, 2006). Failure to do this can bring global shame or legal sanction upon a nation state (Cole, 2005).

One criticism of world society theory, or sometimes called world polity theory, is that it operates at a somewhat broad or general level lacking in a good understanding of how global norms get grounded in specific empirical cases and does not have much to 
say about national and local level human actors and whether or how they domesticate these global scripts for their immediate local context. Put another way, world society theory represents a kind of global-to-local analysis as compared to a local-to-global model or one that interrogates collisions between the local and the global (Mazlish, 2005; Ruodometof, 2005). Notwithstanding this shortcoming, world society theory has considerable analytical purchase, as I hope to show, in terms of helping one to understand and explain the mnemonic life-cycle or trajectory of Bloody Sunday memory.

Admittedly, the Giddens analysis about dis-embeddedness and deterritorialization and the world polity perspective focusing on the territorial nation-state as a modular node embedded in a world society orbit, represent different ways of thinking - 'stories' - about the dynamics of globalization, but they both converge in a strong and convincing challenge to the state-centric analyzes mentioned earlier.

Despite the obvious affinity in concerns about time and space, very few scholars have explicitly sought to bring the insights of globalization research to bear on collective memory research even though one sometimes sees passing references to globalization in the academic literature on collective memory and vice versa (Misztal, 2003: 18; Bell, 2006: 3). But, for the most part, collective memory studies have not engaged with globalization research and a regrettable consequence of this is that the two literatures seem to have been talking past one another for quite a long time, or at any rate, have rarely come into contact. As Ulrich Beck neatly puts it, 'there has been a great deal of thought about the globalization of space and location, but much less about the globalization of time and of memory' (Beck, 2002: 31). Jennifer Jordan’s recent work on 
factors influencing forgetting and remembrance in urban Berlin exhorts scholars to correct for this curious omission (Jordan, 2006: 21-22).

One major notable exception to this inattention to memory in globalization research is the recent work of David Levy and Natan Sznaider under the title The Holocaust and Memory in the Global Age, which explicitly examines memory in the global context (Levy and Sznaider, 2006, 2002). This ‘cosmopolitan memory’ involves a kind of double movement of de-territorialization and re-territorialization, on the one hand leading to a heightening of the importance of globalizing memories and on the other their adaptation for local tastes and traditions. For Levy and Sznaider, the mass electronic media of film and the internet is crucially implicated in this process because of its capacity to diffuse images around the world, collapsing time and space, while at the same time these are interpreted and processed locally. In contrast to critics of the mass culture industry, they offer a strong defense of the electronic media's representations of the past as standing up to tests about authenticity. They are careful not to liquidate the nation altogether by insisting that their work 'no way implies the end of nationally based structures of remembrance' (Levy and Sznaider, 2006: 28) only 'the rise of the global as a context and means for national cultures' (Levy and Sznaider, 2006: 182). Because the local and the global interact in interesting ways, Levy and Sznaider find Roland Robertson's concept of glocalization as a useful frame of reference in their thinking about cosmopolitan memory. This memory is as much future-oriented as it is past-directed. Taking the example of Anne Frank's book, they claim it is 'coming to represent much less a past characterized by evil than a message for the future that transcends the past' (Levy and Sznaider, 2006: 190). I agree with Levy and Sznaider’s claim that there are 
crucial linkages between the global and the local but the crucial role of local level actors (memory entrepreneurs) as interpreters and filters of global memory narratives, symbols and themes is given insufficient attention in their work.

While Levy and Sznaider's work does pay attention to a new globalizing of memory, we still get the impression from their research that the global language about memory exists without a context for framing it. Put another way, we're left wondering about how the new global idiom around memory gets constructed at local level through texts like websites, museums, exhibitions and the like, as well as through embodied forms of remembrance such as marches and processions (Spillman and Conway, 2007), all of which are the product of decades of creative and intensive memory entrepreneurship. To help rectify this somewhat de-contextualized, de-localized view of memory, and following recent sociological efforts aimed at 'grounding globalization' (Burawoy at al, 2000: 341), I propose to examine collective memory with reference to the case of Bloody Sunday (1972), by paying attention to the logic shaping the choices memory entrepreneurs make about how the past should be remembered. I try to make the argument that active local-level memory entrepreneurship is crucial to the constituting of memory narratives in terms of a global frame of reference and that this local-level identification is heightened in the context of Northern Irish society, in which two opposing group identity categories claim political allegiance to two different states (BenPorat, 2006). But the global institutional environment also matters here and specifically I argue that the 'clever' reframing of Bloody Sunday in the abstract idiom of human rights can be explained in terms of world polity theory, and its emphasis on the institutionalization, diffusion and legitimation of a universal human rights discourse 
(Cole 2005). ${ }^{3}$ It can also be explained by propitious Irish, British, European, American and global influences as well as political, economic and demographic changes that came together in the mid-1990s. Finally, I attempt to draw attention to the limits and possibilities of this global story-telling in relation to remembrance and commemoration.

\section{The Bloody Sunday Case}

Bloody Sunday was not just an event in which thirteen civilians, all Catholic, workingclass men, lost their lives while peacefully marching against internment in Derry, Northern Ireland, on 30 January 1972. It is also among a number of events through which

a whole decade, 'the seventies', has come to be remembered, a downbeat decade of world economic crisis and political quarrelling between east and west (Cleary, 2007:95). In very many accounts of this decade the events of 30 January 1972, are mentioned alongside other events like the oil crises and the emergence of rock music bands like U2 and the Rolling Stones. Within a few hours of the shooting, 'Bloody Sunday' entered Northern Irish public discourse and in the process invoked the memory of earlier 'Bloody Sunday' events (Schudson, 2001; Conway, 2005) most notably in November 1920 when spectators at a Gaelic football match in Dublin came under fire from British soldiers (Conway, 2005).

The official state memory of the event was recorded in the Widgery Report but from the very beginning the vernacular nationalist community articulated its own definition of the situation that collided with the official narrative and mobilized Bloody Sunday as a key symbolic resource in constructing its oppositional group identity (Conway, 2003, 2005; Spillman and Conway, 2007). I am particularly interested in the 
fact that in recent years, Bloody Sunday has been framed in increasingly global terms as a collective symbol of injustice and oppression, analogous to the narrating of the Holocaust $^{4}$ as a universal symbol of the human capacity for evil (Alexander, 2003; Levy and Sznaider, 2006).

From the beginning though Bloody Sunday was framed in global terms, being referred to in newspaper coverage in the first few days after the event in terms of other already institutionalized historical events (Beim and Fine, 2007; Gregory and Lewis. 1988), for instance, as 'Derry's Holocaust' and as 'Our Sharpville'. The use of these linkages with already institutionalized events may well have helped to give the event resonance with a wider audience during the first few days after Bloody Sunday in which it got global media attention. This early global idiom all but disappeared though in the 1970s and 1980s only to reappear again, in a rehabilitated form, in the mid-1990s. At this time also, Bloody Sunday became increasingly commodified through the selling of a range of popular Bloody Sunday products like t-shirts, key rings, mugs, posters and CDROMs (Conway, 2005), opening up the interesting question of whether an historical event like this loses its capacity to carry a powerful political message when it becomes touched by commodity material culture (Larson and Lizardo, 2007).

Most informants for this study did not consider popular cultural representations of Bloody Sunday in such things as film as vulgar or inauthentic though these different modes of representation arguably have different memory carrying capacities. One young adult informant, contrasting the docudramas Sunday and Bloody Sunday (both released in 2002), pointed to the realism of film representations and the authenticity of the production achieved through filming on location in Derry city: 
I don't know whether it could have went down the other way...in England or whatever...but in Derry it just seemed far more real...'cause it was Derry people...real Derry accents you know....and it was...you recognized every wee corner, every wee part of it...because most of it...not all of it...some of it was filmed in Manchester I think...but I know a lot of it...most of it was filmed in Derry...a good proportion of it...whereas the other film...a lot of it was filmed in Ballymun I think in Dublin...(Interview with author, 20 August 2004). Another older informant who had direct experience of Bloody Sunday was critical of the use of Hollywood convention in Bloody Sunday: it adopted the standard Hollywood device of seeing the events of Bloody Sunday through the eyes of a central character...once they selected the central character to be Ivan Cooper...once you make that decision then you have to place that character...in order to tell the story you have to place that character at the center of every development and every incident...that you are going to depict...and that required that a role be ascribed to Ivan and to... and therefore to other things that Ivan Cooper represented... which vastly exaggerated the role which he personally had in the politics... (Interview with author, 15 August 2004).

Memory entrepreneurs capitalized on audio-visual technology in a way that was not done in the 1970s and 1980s by instituting an exhibition about Bloody Sunday in a centrally located ‘Bloody Sunday Centre’. This exhibition made use of private artifacts belonging to the victims of Bloody Sunday and brought into focus the complex and interesting relation between private remembrance on the onehand and public commemoration on the other. Displaying emotionally charged objects such as the blood-stained civil rights 
banner carried on the original march, personal items belonging to the dead, and extensive use of eyewitness testimony of people who were 'really there' on the march in 1972 helped underwrite the truth claims (Beim and Fine, 2007) of the nationalist community and contest the official British state memory. The use of an exhibition space in a prominent location in the city as well as the visibility of the event in murals and various consumer items gave Bloody Sunday a year-round visibility, outside of the commemorative Sunday at the end of January, and this helped mobilize support for the families' quest to discern the truth about the event (Conway, 2007).

The following section examines commemorative discourses with respect to Bloody Sunday across three phases (see Table 1) - 1970s, Phase 1 (Oppression and British Injustice), 1980s-early 1990s, Phase 2 (British Injustice but also Equalization of Victimhood) and, mid-1990s, Phase 3 (Truth-Telling, Human Rights and Justice StoryLines) - paying special attention to the third phase in which the event was re-imagined and re-constituted in increasingly global and universal terms. I look at commemorative discourse in this phase, the views and opinions of memory entrepreneurs with respect to it, and then attempt to account for it - moving from the local level up to the global level in terms of a set of Irish, British, European, American, and global influences (some identified by memory entrepreneurs and some not) and shifts at different levels political, economic, demographic - that came together in the mid-1990s (and not in the 1970s and 1980s). Memory entrepreneurs stressed that changing local conditions accounted for new global cultural discourses though the influence of the passage of time could also be considered important and the consequent reduction in the number of living informants with direct experience of the event (Schudson, 2001), that is, people with 
cultural as against communicative memory (Assmann, 1995). In terms of 'discursive horizons' (Fishman, 2004: 63), phase 1 was characterized by an internal exclusive focus, phase 2 by an internal inclusive focus and Phase 3 by an internal and external inclusive focus. This periodization is based on changes in such things as spatial orientations, political projects, and cultural idioms as set forth in Table 1 . This table also briefly summarizes the explanatory framework employed in the article.

Empirically, this article is based on archival research and interviews ${ }^{5}$ with members of the local committee which organizes the annual Bloody Sunday commemoration (Conway, 2005). A wide range of archival material was analyzed in this study including pamphlets, posters, brochures, film footage, and newspaper articles. For this research I visited two archival repositories: the Northern Ireland Political Collection at the Linenhall Library, Belfast, and the Radio Telifís Éireann (RTÉ) Archives, Donnybrook, Dublin. In the Linenhall Northern Ireland Political Collection I examined the Bloody Sunday boxes, Northern Ireland Civil Rights Association boxes, Civil Liberties Organizations boxes, Civil Rights Organizations boxes, Murals box, Provisional Sinn Féin boxes, Northern Ireland Office Cuttings Files (Londonderry Civil Rights March 30.1.1972, Civil Rights Association, Bogside and Creggan, Londonderry, Londonderry Development Commission, People’s Democracy boxes. In the RTÉ archive I examined film footage of Bloody Sunday commemoration marches. I also carried out documentary research in the Central Library, Derry, where I examined the library's newspaper clippings collection on the following topics: Bloody Sunday clippings and other relevant material, Murals, Bogside, Bogside Artists, Artists, Bogside, Gasyard, Brandywell, Bogside Community Association News file, Creggan News file and Creggan 
Magazines (General) file. I also examined the library's microfilm archive of the Derry Journal and Londonderry Sentinel newspapers for media coverage of Bloody Sunday commemorations from 1972-2006. In addition to this, I examined commemorative posters, brochures and other ephemera held in the Museum of Free Derry, then located at the Gasworks, Bogside, Derry. I also carried out a participation observation study of the 2004/2005/2006 Bloody Sunday commemoration marches.

Following Hill's observation that 'researchers continually reshape their understanding of the past as they fit, sort, shift, and reinterpret more and more data into evolving sociohistorical frameworks - guided by theory and creative sparks of insight' (Hill, 1991: 68), I approached the archive in an iterative way. By this is meant that as I visited each archive on a number of different occasions I attempted to make sense of earlier examinations of the material in the light of new finds or new data. I also thought of the archival and interview data collection not as mutually exclusive but as processes that guided each other. I used the interviews as an 'auxiliary method' (Kvale, 1996: 98) in conjunction with the archival data collection in that new data that emerged through one guided the collection of data through the other. For example, early on in my fieldwork key-informants made reference to commemorative activity such as the Guildhall stainedglass window that I did not know about from my earlier archival work and this led me to follow up debates around this in my later archival visits. In this way, new and unanticipated questions, angles, complexities and insights continually emerged in the back-and-forth dialogue between the interviews and the archival work.

The archival data analysis process involved the organization of the material in a temporal and topical way (Hill, 1991). I organized the archival material by topic - such 
as the march, the Guildhall stained-glass window, the murals, the memorial and so on, and with respect to the march which was the main focus of the present paper, I organized the material temporally, that is by decade. I read and reread each article about the commemoration in each year paying attention to whether a local or global discourse was employed in accounts of political discourse at the marches. I constructed a spatiotemporal chronology of Bloody Sunday commemorative marches, from my reading of newspaper accounts and my viewing of film footage, focusing on variation over time in commemorative themes, references to other societies with similar experiences, controversies surrounding the march, attendance levels, the route of the march, and speakers who addressed the march. I also analyzed commemorative brochures and posters, again focusing on the extent to which each used local/national as against global imagery and symbolism.

Interviews were carried out with ten members who sat on the local committee which organized the Bloody Sunday commemorations. These interviews followed an interview schedule but were flexible enough to take account of different levels of knowledge of different sites of memory among informants and of variations in duration of participation in the local organizing committee among different members. Because I was interested in a particular group of people - those directly involved in organising Bloody Sunday commemoration events or those involved in controversies associated with it - I followed a purposive snowball sampling procedure (Sarantakos, 1993) after making first contact with the local organizing committee. Each interview was recorded and transcribed and observations about the setting of each interview and such things as unexpected interruptions, the atmosphere, and the extent to which the interviewee made 
me feel welcome were noted. After transcribing each interview I developed a coding scheme to help make sense of the data. This focused on references to global events and circumstances, reasons respondents gave for commemorative strategies, and the constraints and opportunities influencing commemorative activity. The next section of the paper examines the three historical phases in turn.

Table 1 about here

\section{Historical Period 1: Oppression and British Injustice}

Irish republicans were quick to claim that the memory of Bloody Sunday 'belonged' to them. After a short political contest with a weaker rival it became the hegemonic organiser of the annual commemoration (Conway, 2007). The early 1970s, these commemorations, as the Northern Ireland conflict intensified, were characterized by an emphasis on nationalist victimhood and British injustice ${ }^{6}$. Irish republicans repeatedly drew attention to the British state's ill-treatment of republican prisoners, its status as an unwelcome colonial power, and the need to bring about the earliest possible unification of Ireland and the end of the union with the British mainland (Conway, 2003, 2005, 2007). In this narrative there was little or no reference to republican violence or to their responsibility for killing members of the British state or members of the Protestant community. It was easier in this period to forget these unsavoury deeds and to focus 
instead on British state violence. Protestant or unionist participation in the commemoration was virtually absent as memory entrepreneurs adopted an exclusive understanding of the relevant 'public sphere'. For example, the public announcement for the fourth anniversary commemoration in the republican newspaper An Phoblacht claimed that 'those who died on January 30, 1972, were taking part in an anti-internment protests. Internment has now ended, in name at least but there are still almost 2,000 men and women held hostage by the British’ (An Phoblacht January 16 1976: n.p.).

Political rivals also came under rhetorical attack especially constitutional nationalists in the Social Democratic and Labour Party. At the 1979 rally, Sinn Féin’s Marie Collins rebuked the SDLP claiming that 'we don't see them marching arm-in-arm today. They have been eaten up by the system’ (An Phoblacht 3 February 1979: n.p.).

\section{Historical Period 2: British Injustice but also Equalization of Victimhood}

Although the emphasis on drawing attention to examples of British injustice did not disappear during this stage, there was a new focus on challenging a 'hierarchy of victimhood' that privileged the suffering of the nationalist community (Conway, 2005). This was clearly articulated in the debate around the design and construction of the Guildhall stained-glass window commemorating the events of 30 January 1972, the first state-sponsored effort to remember the event albeit in the context of 'civic remembrance' and commemorating a broader range of victims of the conflict. During debates among the city's political leaders, politicians representing the Protestant community were at pains to clearly distinguish between victims and perpetrators of the Troubles. Within this framework, paramilitaries lied firmly on the side of the perpetrators of violence against 
innocent and often indiscriminate victims, often citizens but also representatives of the state including the police and army. Nationalist politicians sought to give symbolic recognition to people's suffering during the Northern Ireland conflict apart from that on the nationalist-Catholic side (Conway, 2005).

\section{Historical Period 3: Truth-Telling, Human Rights and Justice Story-Lines}

This period was characterized by a new emphasis on recalibrating republican's definition to victimhood to encompass people's in distant places as well. The valency of Protestant victimhood as a result of the Troubles was also rhetorically acknowledged. Speakers at the commemoration were inclined to mention that Protestant community suffered as well during the long period of the Troubles and that no one tradition had a monopoly on suffering. Commemorative discourse then spoke to the political circumstances of the early 1990s and Bloody Sunday remembrance represented an important opportunity for the republican community to give rhetorical support for constitutional politics - chiefly by purging commemorative discourse of anti-British and pro-violence sentiments - and demonstrate the credentials of leaders within it as peaceful democrats. At the same time, the quest for the unity of the island of Ireland remained a key focus but through a new means of peaceful dialogue and debate.

In the 1970s and 1980s, unionist opinion tended to be hostile to the Bloody Sunday commemorations. Politicians in southern Irish society paid little attention to it and were regularly criticized on the platform by speakers from a militant republican tradition. In the 1990s memory entrepreneurs went to some lengths to seek the support of southern political élites behind the campaign for a new inquiry into the events of 30 
January, 1972. During a visit to Northern Ireland in 1998 Taoiseach (Prime Minister)

Bertie Ahern laid a wreath at the Bloody Sunday memorial. Protestant political leaders, ignored in the 1970s and 1980s, were invited to participate in Bloody Sunday seminars as part of a more celebratory commemorative programme.

The 1990s was marked by particularly intensive memory entrepreneurship around Bloody Sunday. It seemed that as people's temporal distance from the original event increased, memory makers worked harder at preserving the memory of the event. An editorial in the Derry Journal newspaper pointed out that 'from the British point of view, however, Bloody Sunday has become much more than a far-off disaster that is remembered once a year. It is now an issue that almost daily conjures up ghosts to haunt the British establishment. Slowly more and more of the truth emerges. ${ }^{7}$ In the mid 1990s, and in the lead up to the $25^{\text {th }}$ anniversary commemoration, an effort was made to put together a 'people’s archive' as a counterpoint to the official history and as a way of providing an empirical basis for nationalist truth claims that contested the dominant story. This effort to preserve individual and collective memories of Bloody Sunday got underway through a public call in the local press inviting contributions to a permanent archive with a declaration that 'unless people here now start to create their own archive of January 30, 1972, the official history will be the only substantial version left for future historians to judge. A People's Archive will set the record straight. ${ }^{8}$ In this account, the official narrative is constructed as a 'lie' and the vernacular memory as 'authentic'. The Saville Inquiry itself has brought private memories of the event into the public sphere, some so traumatic that they not spoken about since the original event, and has kept Bloody Sunday a live public issue. 
Don Mullan’s groundbreaking book Eyewitness Bloody Sunday (Mullan, 2002), published around the time of the $30^{\text {th }}$ anniversary, put together early oral histories of the event and helped to generate a surge of interest in the commemoration and to keep alive the continuing quest for truth. Organizationally, a plethora of groups emerged during this period - the Bloody Sunday Initiative, the Bloody Sunday Trust, and the Bloody Sunday Weekend Committee - with a focus on Bloody Sunday - some on its commemoration and others on the campaign for a new inquiry - but by the mid-1990s these twin foci became inextricably linked with one another in a way that had not occurred in the 1970s and 1980s. This coupling of commemoration and campaigning was highlighted by one participant in the march:

it is almost a habit that you do the Bloody Sunday commemoration... what it means to me sort of is that I am still campaigning...I see it as a campaigning thing...it can be seen as a commemoration rather than a march like the Poppy Day ceremonies and so on...people go on Poppy Day ceremonies you know in order to achieve any objective...we go because we go. But also and far more importantly from my point of view...to see this issue through and to see the truth acknowledged by the British authorities about what happened in Derry. So when I go on it is sort of...basically I'm campaigning...it is part of a political campaign...(Interview with author, 15 August 2004).

A wide range of cultural artifacts were deployed to infuse everyday social life with references to Bloody Sunday and to make it difficult to forget the event ranging from street murals to mug coasters though some of these - such as the mural painting evoked local controversy. In the case of one of the Bloody Sunday murals - a 
juxtaposition of the civil rights struggle and Bloody Sunday -a debate was set off in the local press between the painters of the mural and local Derry journalist Nell McCafferty for the alleged gendered representation of the past that the mural seemed to put forward and specifically its symbolic exclusion of women - who were key civil rights agitators in Northern Ireland - from the historical narrative (Conway, 2005).

The most noteworthy feature of this historical phase though was the re-imagining of Bloody Sunday as an example of injustice with parallels in different parts of the world. Parallels tended to be drawn with the circumstances of places like Israel-Palestine, South Africa, and Mexico though, as one memory entrepreneur explained, these parallels often are 'historically inaccurate and at the very least a grotesque exaggeration of the suffering of Northern Catholics' (Interview with author, 15 August 2004). The globalizing theme of the 1990s was manifest in a number of ways but one of the most interesting expressions of it was the commemorative poster for the $2002^{9}$ commemoration which carried a picture of a flower juxtaposed against a background of a large assembly of people. On the face of it, the orange flower seemed unremarkable but on careful inspection the ovary of the flower revealed a small globe. This use of photomontage was a clever and creative piece of iconography by that year's Bloody Sunday commemoration organizers and was part of an effort to explicitly link the event to different examples of human injustice in different parts of the globe. Other aspects of the 2002 commemoration reinforced the international idiom - mentions of other world troublespots in public discourse, film screenings about war-torn locations, references to other conflict zones such as Israel-Palestine, and the flying of flags representing colonized peoples. 
When I asked interviewees about the feel-good and upbeat globalizing discourse of the 1990s the significance of media and public relations skills among memory entrepreneurs and crucially, changed local political conditions, were emphasized. One memory entrepreneur explained:

I think we are just getting better at what we are doing. That's part of it. We, people involved in the committee, there is an awful lot of skill in the committee. People who have been involved in events like this, not only the Bloody Sunday Weekend Committee, but other campaigns and other community issues. So people are just becoming, from one point of view, the committee is getting better and better at organizing things. We've been doing it for years so you learn from your mistakes. You don't make them again, you get a bit more ambitious. There is also the issue itself has become so much more internationalized over the past 10 years or more, I suppose with the peace process and stuff like that it is easier to get the issue out. While the war was going on it was always easy to keep the issue alive within our own community but while the war was going on it was another part of the war so getting it international wasn’t quite so easy you know. There was always international support on the issue but it is easy to use it I suppose when there isn’t a war going on in the background. Just we have tried to make it better and more ambitious every year and I suppose to a degree we are succeeding in doing that (Interview with author, 29 July 2004).

Memory entrepreneurs spoke of the importance of the Northern Irish peace process in creating a new political environment for a global idiom about Bloody Sunday. One spoke about how 'the war', that is, the violent paramilitary campaign against the 
British occupation of Northern Ireland, acted as a constraint on the ability of memory entrepreneurs to construct a discourse about global human rights and justice. The same 'war' helped to ensure the resonance of Bloody Sunday 'within our own community' but not beyond it, particularizing it within a bounded field at a particular point in time. He was keen to emphasize the importance of the experiential as well by relating that 'we've been doing it for years so you learn from your mistakes. You don’t make them again, you get a bit more ambitious' (Interview with author, 29 July 2004).

Another important factor influencing the 'easy listening' universalizing discourse had to do with pragmatic reasons. In the 1970s and 1980s, Sinn Féin was the dominant organizer of the Bloody Sunday commemorations but was not was capable of securing the support of all the families of the victims of Bloody Sunday because of its avowal of violence as a mechanism for bringing about political change and its marginalization from the political mainstream as a result. As one entrepreneur articulated, 'there was an effort by some in the republican movement to pull the families together. And you wouldn't have got all the families buying into it. So we had to get rid of the party politics' (Interview with author, 26 July 2004). Draining the commemorations of its explicit republican coloration then became an important strategy of memory entrepreneurs keen on building an alliance of political actors in their quest for truth about what happened on 30 January 1972, that went beyond the street politics of marching and holding rallies that Sinn Féin was a key force in: 'we needed the likes of John Hume to be seen on television to be photographed with the Bloody Sunday families for people to see and understand this is not a republican event this is about the actual events of Bloody Sunday. There was a lot of work and effort put into that' (Interview with author, 26 July 2004). In this 
account, the adoption of a language of human rights and social justice is linked to the republican strategy of seeking the symbolic support of northern (and southern) political élites behind the campaign for a new inquiry.

Crucially this reframing of Bloody Sunday as was done through the deployment of a human rights and justice interpretative framework and in a way that helped to neutralize earlier criticisms that the event was overly identified with and almost exclusively claimed by Irish republicans: 'Bloody Sunday always had to be viewed as a human rights issue. Of course...the politics of nationalists and Britain existed...but Bloody Sunday had to be seen as a human rights issue. If we had tried to move forward without the support of the SDLP...Martin McGuinness and Gerry Adams at that time could not have done us favors in London’ (Interview with author, 26 July 2004).

Political pragmatism then motivated the desire to liquidate the republican reputation that the Bloody Sunday commemorations developed and that alienated a number of significant potential political allies. For this to happen, Bloody Sunday had to be reconfigured and rebranded as not just an event that happened in Derry and that only mattered to Derry people but one that would resonate with people well beyond the city of Derry. As one organizer of the annual commemoration put it: 'I think it was important that it was seen to be organized by a broader group...that was made necessary...that was necessary in order to advance the campaign for a new inquiry in the early 1990s’ (Interview with author, 15 August 2004).

Another memory entrepreneur also pointed to the crucial platform the commemoration of the event created for increasing the visibility of the campaign for a new inquiry, elaborating that: 
it reflected pragmatism at the time...the Bloody Sunday Initiative was the first organization set up and it took on a few objectives...some were about Bloody Sunday and some were about developing a radical political agenda on human rights...you had two strands of thinking from the very very start... and due to success I suppose the nature and basis of the organization had to change... because the Bloody Sunday Initiative was very very successful in relation to creating a focus around the issue of Bloody Sunday...after a while once that focus was successfully created...after 1992...it was felt that the mix...the issue of Bloody Sunday with a whole range of issues within the one organization didn’t really do it justice... and it needed to be...it needed to sort of create a single focus (Interview with author, 9 August 2004).

In this account, memory entrepreneurs make little or no reference to the constraints imposed by earlier meanings attached to Bloody Sunday, as Olick's processional model would lead one to expect. Rather we see an emphasis on pragmatic politics shaping the choices memory workers make in relation to remembrance and little concern about the difficulties created by earlier, and very different, meaning-making around the event. For all of Sinn Féin's efforts to fix the meaning of the event as a constant reminder of the evils of British imperialism, by the 1990s Bloody Sunday was open in semiotic terms (Spillman, 2003) and the open-ended nature of its meaning may help to ensure its salience among future generations with no direct, lived experience of it (Assmann, 1995) and who come into contact with it only through the kind of mediated cultural memory - books, websites, songs, poetry, films - that intensified in the 1990s. 
Beyond pragmatic considerations identified by memory entrepreneurs - such as Bloody Sunday's potential as a usable past in the politics of the present - what others factors help account for the global turn in Bloody Sunday memory in the mid-1990s? Why did the discourse of 'justice' and 'human rights' emerge in the mid-1990s and not earlier? In the 1970s and 1980s, the Northern Ireland conflict, as Ben-Porat argues, tended to be viewed as a conflict that was unfixable (Ben-Porat, 2006). The depth of ethno-national division built up over a long history of hostility resulted in two silo communities each with different group identities. These opposing identity categories were concretized in the material conditions of the society and in relationships with the British state. Historically, Catholics were materially less advantaged and developed an antagonistic relationship to the state. But owing to the coming together of global factors, European influences, and shifting local conditions in the 1990s, this prevailing view became unstuck and bringing politically motivated violence to an end began to seem attainable as a long-term goal. Macro structural changes such as changing demographics in Northern Ireland meant that Catholics represented a higher, and increasingly confident, proportion of the population in the 1990s than they did in the 1970s and 1980s. In 1970, Catholic represented 37\% of the population compared to 44.5\% in 2001 (Fitzgerald, 2005: 152; Ben-Porat, 2006: 203). Economically, Northern Ireland in the 1970s fared poorly and was heavily subsidized by the British government. Its economy picked up especially its manufacturing sector - in the 1990s with the securing of the peace process (Fitzgerald, 2005; Ben-Porat, 2006).

Changes within the nationalist community itself, shaped by broader political changes in Britain and Ireland, led to a slow rethinking of the political costs and benefits 
of continuing the 'armed struggle'. Strong nationalist support, as reported in opinion poll data, for maintenance of the union with the United Kingdom made the quest for Irish unity - and through violent means - more difficult to justify and mobilize around. Crucially, republicans began to develop political networks, via reciprocal visits, with leaders of and actors in other struggles against oppression in places such as South Africa and Mexico (Adams, 2003; Derry Journal, June 11, 1996: 15) and these networks provided an important framework for the discursive construction of the Northern Irish conflict. The adoption of a universalizing idiom was made easier by the fact that international themes were already well articulated in other forms of Irish nationalist commemorative iconography. For example, the use of international symbols and images in republican mural painting began to emerge in the 1980s and sought to draw parallels between the Northern Irish situation and oppressed peoples such as Blacks in America and South Africa (Rolston, 1991).

The political context in Britain changed in the 1990s too with the election of 'New Labour' with a majority in Westminister that gave it more leverage with respect to accommodating the concerns of Irish nationalism that earlier Conservative governments did not enjoy (Ben-Porat, 2006). In the 1970s and 1980s British political opinion converged on the point that a way out of the Northern Ireland conflict could be found only through a military and security strategy. At street level, this manifested itself in poor relations between the security forces and the local nationalist population and fueled nationalist grievances vis-à-vis the British state that were articulated at Bloody Sunday marches. In this climate, finding a negotiated political solution had little currency. 
Neither did the British government give more attention to recognizing the role of the Irish government in securing a settlement (Fitzgerald, 2005).

In the 1990s political changes south of the border involved an increasing willingness to deal with and compromise on the old chestnut of the territorial claim to the northern six-counties, an increasing awareness of this as a blockage to a negotiated settlement, and an acceptance of the principle of consent with respect to changes in the status of Northern Ireland. The overcoming of the ‘territorial trap’ (Brenner, 1999; BenPorat, 2006) by globalization gave a new impetus to attempts by peace entrepreneurs around this time to refine the Northern Ireland conflict as one having to do less with territory than with people and how they might live amicably and harmoniously together. This was linked, in line with world polity theory, to an increasing emphasis on Ireland's image and standing on the world stage and the extent to which the Northern Ireland conflict undercut this 'nice', modern, progressive societal image that cultural and political élites sought to promote in order to secure material and symbolic advantages (Conway, 2006; Ben-Porat, 2005).

In the 1980s and 1990s, successive Irish governments engaged with the British government in seeking to bring about an end to the conflict. Convincing the British side of the counter-productive nature of its earlier security solution and of the value of Irish input in the affairs of Northern Ireland, represented key goals of this engagement process and helped to tilt public support away from militant republicans towards the moderate nationalism of the Social Democratic and Labour Party (Fitzgerald, 2005). The AngloIrish Agreement of 1985 codified this and gave the impetus for an internal debate within 
the Irish republican movement about moving towards a political route to securing its long-standing goal of a united Ireland (Fitzgerald, 2005; Ben-Porat, 2006).

Across the Atlantic, a favorable political environment, most notably a US President, Bill Clinton, sympathetic to and interested in the Irish Question and a wider Irish-American constituency willing in support (O’Clery, 1996; Cochrane, 2007; BenPorat, 2006), created a propitious context for seeking a resolution of the conflict and pointed to the growing internationalization of it. This American mobilization of 'soft' power helped to nudge Irish republicans in the direction of pursuing their goals through political processes (Cochrane, 2007). An index of this was the regular participation of Ancient Order of Hibernian branches from America in the Bloody Sunday marches in the 1990s. At a European level, Ireland's membership of the European Union (EU) meant that it was a net beneficiary of transfers from the EU and this made its catching up - in terms of infrastructure and public finances - with other more prosperous countries possible, helping, in turn, to equalize the Anglo-Irish relationship (Fitzgerald, 2005; BenPorat, 2005). Within this equalized relationship, Bloody Sunday became a usable past in the context of the developing and ongoing peace process.

Globally, examples of successful resolution of old and long-standing political conflicts (Ben-Perot, 2006) such as the ending of the Cold War, the demise of communism in Poland, the reunification of Germany, and the end of apartheid in South Africa, provided an important frame of reference for political leaders in Northern Ireland and sent out a clear message that apparently unsolvable political quarrels could be brought to an end. A shifting global institutional environment, specifically one with increasing emphasis on a universal conception of human rights that became a peculiar 
and noteworthy feature of western political culture from the 1970s on (Cole, 2005) also helped to motivate and underpin this move from 'licking one's own wounds' towards a translocal idiom of 'cross-national solidarity' (Gibbons, 2005: 564) All of these influences - Irish, British, European, American, global - and shifts at different levels political, economic, demographic - that came together in the mid-1990s (and not in the 1970s and 1980s) reconfigured the political context of Northern Ireland and created a new environment within which global symbolism and idioms could find a resonance.

\section{Conclusion}

This article has sought to map and explain the memory discourses and commemorative strategies around Bloody Sunday across three historical phases scrutinizing in particular the period from the mid-1990s on. An analysis of these phases suggests that there was a slow but discernible shift in meaning-making from an early exclusivist interpretation of the meaning of Bloody Sunday to a more inclusive, pluralist one in which memory entrepreneurs sought to appeal to multiple audiences (Fine, 2001) for whom Bloody Sunday could or did have resonance and a positive valence. ${ }^{10}$

In the 1970s and 1980s Irish republicans colonized the memory of Bloody Sunday and in so doing went to great lengths to construct the British state as an 'other' and this clearly fitted well with its colonial interpretation of the Irish Question. Within this discursive framework the Bloody Sunday victims were repeatedly invoked as martyrs who died in the struggle for liberation from British imperialism and mobilized them to symbolically contest the British presence in Northern Ireland, a key republican goal. At the same time, Bloody Sunday commemorations, as with other republican 
commemorations, were occasions for bringing republicans together and creating a sense of community and connection among them. The 1990s - during the 'Truth-Telling, Human Rights and Justice Story-lines’ phase - was marked by a re-branding of the Bloody Sunday story and the crucial interpretative tool for achieving this, as we saw earlier, was the clever deployment of a normative human rights/justice framework that helped to lift the event out of an earlier Irish republican interpretative model and liquidate it of its unsavory connections to the use of violence and physical force as a political weapon. In this phase, Bloody Sunday did not mean the same thing that it did in the 1970s and 1980s. From the mid-1990s on, a discourse about state oppression did not carry the same force as before and in the 1970s and 1980s it was not globally 'chic"11 to draw attention to cross-cultural parallels with the Bloody Sunday experience.

A commemorative brochure for the 2005 commemoration articulated this connection with global audiences while at the same time grounding the event locally by evoking support for the Bloody Sunday families: 'more generally these events create a space to come and reflect with others on the importance of democracy here and throughout the world and to stand shoulder to shoulder, in solidarity with the families of the victims of Bloody Sunday and victims of injustice everywhere. ${ }^{12}$

This article suggests that earlier commemorations do not have as constraining an influence as one might expect. Indeed, what is striking about this empirical case is how very different later commemorative strategies were to earlier ones signaled by the radical disconnect between early 1970s and mid-1990s framings. The anti-colonial meaning of the commemoration was stabilized throughout the 1970s and 1980s but became unstuck in the 1990s as the organizers of the commemoration sought to disavow the republican 
inflection of remembrance and to move the Bloody Sunday issue into the political mainstream and away from the arena of street politics. Political pragmatism fueled by a shifting local political setting, rather than the constraints imposed by earlier prior commemorations, together with a propitious global institutional environment, fueled this important symbolic shift in Bloody Sunday memory work. The extent to which this transnational, cross-cultural identification with casualties of injustice in other parts of the world with whom one has no face-to-face contact can be sustained over the long-term or more importantly whether it motivates solidaristic human action - sending money to assist victims of injustice or lobbying political actors on their behalf, for example - is an open question.

The world polity approach has some 'legs' in terms of explaining the global storyline that was a feature of Bloody Sunday discourse from the mid-1990s on. In particular, the trajectory of Bloody Sunday memory mapped out in this paper, in terms of (a) a shift from particularism and localism to abstract ideas about human rights and (b) the diminishing importance of local conditions over time and the parallel heightened importance of the global environment, is wholly consistent with the predictions of this theory. But it may well be that this scaling up in Bloody Sunday memory - from the local to the global - will lead to a liquidation or hollowing out of its local meaning a 'de-vernacularizing' of Bloody Sunday - and that it will become an empty shell onto which a range of meanings, with little direct connection to the original events, can be attached. However, the global side of this explanation is not the whole story. I have tried to argue that it is a combination of and interaction between shifting local conditions and a global political environment that helps explain the global turn in commemorative 
strategies. In this global story telling, local memory entrepreneurs, embedded in both a local context and a global environment, exercise control over the framing of Bloody Sunday in translocal terms while at the same time being subject to the proliferation of private memories that broke out into the public domain during the recent Saville Inquiry and the semiotic openness of the event. Together, these two factors have the potential to lead to a kind of fragmentation, instability and pluralization of Bloody Sunday memory in the future and a consequent loss of control over the meaning of the past ${ }^{13}$.

By drawing attention to key influences - Irish, British, European, American, global - and changes at different levels - political, economic, and demographic - that came together in the mid-1990s (and not in the 1970s and 1980s) and that had the effect of reconfiguring the political context of Northern Ireland and creating an important environment within which global symbolism and idioms began to develop a currency among memory entrepreneurs and a wider public, this paper provides an explanatory framework - linking macro structural, political and economic shifts to micro interpretations and meaning-making - for understanding the trajectory of memory work with respect to the case of Bloody Sunday. 


\section{Notes}

1 An earlier version of this paper was presented in the Memory, Culture and Conflict Research Stream, European Sociological Association, Glasgow Caledonian University, Glasgow, Scotland, 3-6 September 2007.

2 The full study is Boli, J. and Thomas, G. M. (eds) (1999) Constructing World Culture: International Non-Governmental Organizations since 1875. Stanford: Stanford University Press. A shorter truncated version of this is contained in Meyer, 2004.

3 I owe this point to an anonymous reviewer.

4 The analogy between the Holocaust and Bloody Sunday is a false or unsuccessful one when one considers the vast difference between the two events in terms of loss of human life and the sheer scale of destruction wrought.

5 The full study (Conway, 2005) involved carrying out thirty-one interviews with local clergy, politicians, journalists, community organizers, and members of the local organizing committee for Bloody Sunday commemorations. I thank an anonymous member of this committee for help with gaining access to digitized copies of Bloody Sunday commemoration posters, brochures and other archival material.

6 In earlier work (see Conway 2005, 2007; Spillman and Conway, 2007) I focused on contestation within the nationalist community about the meaning of Bloody Sunday, paying particular attention to the interpretative struggles between Sinn Féin, on the onehand, and NICRA (Northern Ireland Civil Rights Association), on the other in the early 1970s period. For the purposes of this paper I focus on the 
commemorative strategies of the Bloody Sunday Initiative/Bloody Sunday Weekend Committee/Bloody Sunday Justice Campaign in the 1990s. These three groups were involved in one way or another in organizing the annual commemorations. Notably, the membership of each group overlapped a good deal and where one left off and another takes up is somewhat unclear. The Bloody Sunday Justice Campaign was established on April 17, 1992. Two other organizations with Bloody Sunday in their title also existed during this time period - the Bloody Sunday Initiative and the Bloody Sunday Weekend Committee. All three groups retain some links with Sinn Féin. I use the terms 'memory entrepreneurs', 'memory choreographers', and 'memory makers' interchangeably in the article.

7 The Questions Proliferate. Derry Journal 28 January 1992.

8 Archives project for Bloody Sunday inquiry. Derry Journal 3 February 1995.

9 The theme of the 2002 commemoration, 'One World, Many Struggles', foregrounded the similarities between the Bloody Sunday case and other examples of injustice across the globe, clearly invoking a global interpretation of the tragic events of January 1972 (Conway, 2005).

10 The concepts of salience, valence and ownership as applied to commemoration come from the work of Jansen (2007) though his research is intentionally limited to historical figures rather than historical events.

11 I owe this point to Dr. Rebecca King-Ó Riain.

12 ‘Time For Truth: From Bogside to Basra’ Brochure for 2005 Bloody Sunday Commemoration. 
13 How Bloody Sunday will be remembered into the future is an open question. One informant invoked the 'never forget' mnemonic device (Beim and Fine, 2007) in articulating the continuing localized symbolic importance of the event for Derry people: 'I think it should be commemorated in some way. Bloody Sunday should always be commemorated. I'm not sure how. It cannot never be allowed to be forgotten. Not in this city here’ (Interview with author, 26 July 2004). 


\section{References}

Adams, G. (2003) Hope and History: Making Peace in Ireland. Dingle: Brandon.

Assmann, J. (1995) 'Collective Memory and Cultural Identity’, New German Critique 65: pp. 125-133.

Alexander, J. (2003) 'On the Social Construction of Moral Universals: The "Holocaust" from War Crime to Trauma Drama', in J. Alexander (ed) The Meanings of Social Life: A Cultural Sociology. Oxford: Oxford University Press.

Bell, D. (ed.). (2006) Memory, Trauma and World Politics: Reflections on the Relationship between Past and Present. Hampshire: Palgrave.

Boli, J. and Thomas, G. M. (eds). (1999) Constructing World Culture: International Non-Governmental Organizations since 1875. Stanford: Stanford University Press.

Beck, U. (2002) 'The Cosmopolitan Society and its Enemies', Theory, Culture and Society 19 (1-2): pp. 17-44.

Beim, A. and Fine, G. A. (2007) 'Trust in Testimony: The Institutional Embeddedness of Holocaust Survivor Narratives', European Journal of Sociology XLVIII (1): pp. 55-75.

Ben-Porat, G. (2006) Global Liberalism, Local Populism; Peace and Conflict in Israel/Palestine and Northern Ireland. Syracuse, NY: Syracuse University Press.

Brenner, N. (1999) 'Beyond state-centrism? Space, territoriality, and geographical scale in globalization studies’, Theory and Society 28: pp. 39-78.

Brubaker, R. and Feischmidt, M. (2002) '1848 in 1998: The Politics of Commemoration in Hungary, Romania, and Slovakia', Society for the Comparative Study of Society and History 44 (4): pp. 700-744.

Burawoy, M., Blum, J.A., George, S., Gille, Z., Gowan, T., Haney, L., Klawiter, M., Lopez, S.H., Ó Riain, S. and Thayer, M. (2000) Global Ethnography: Forces, Connections, and Imaginations in a Postmodern World. Berkeley: University of California Press.

Cleary, J. (2007) Outrageous Fortune: Capital and Culture in Modern Ireland. Dublin: Field Day Publications.

Cochrane, F. (2007) 'Irish-America, the End of the IRA's Armed Struggle and the Utility of 'Soft Power', Journal of Peace Research 44(2): pp. 215-231. 
Cole, W. (2005) 'Sovereignty Relinquished? Explaining Commitment to the International Human Rights Covenants, 1966-1999', American Sociological Review 70: pp. 472-495.

Conway, B. (2005) 'Texts, Bodies and Commemoration: Bloody Sunday (1972) as a Case Study’, Ph.D. diss., University of Notre Dame, Indiana.

Conway, B. (2003) 'Active Remembering, Selective Forgetting and Collective Identity: The Case of Bloody Sunday', Identity: An International Journal of Theory and Research 3: pp. 305-323.

Conway, B. (2007) 'Moving through Time and Space: Performing Bodies in Derry, Northern Ireland', Journal of Historical Sociology 20 (2): pp. 103-125.

Conway, B. (2006) 'Who Do We Think We Are? Immigration and the Discursive Construction of National Identity in an Irish Daily Mainstream Newspaper, 19962004', Translocations: The Irish Migration, Race and Social Transformation Review 1(1): pp. 76-94.

Connerton, P. (1989) How Societies Remember. Cambridge: Cambridge University Press.

Fine, G. A. (2001) Difficult Reputations: Collective Memories of the Evil, Inept and Controversial. Chicago: University of Chicago Press.

Fishman, R. M. (2004) Democracy's Voices: Social Ties and the Quality of Public Life in Spain. Ithaca: Cornell University Press.

Fitzgerald, G. (2005) Ireland In The World: Further Reflections. Dublin: Liberties Press.

Giddens, A. (1991) Modernity and Self-Identity. Cambridge: Polity.

Gibbons, L. (2005) ' We Knew Their Plight Well' Race and Immigration in Some Recent Irish Films', Third Text 19(5): pp. 555-566.

Gregory, S.W. and Lewis, J.M. (1988) 'Symbols of Collective Memory: The Social Process of Memorializing May 4, 1970, At Kent State University', Symbolic Interaction 11(2), pp. 213-233.

Halbwachs, M. (translated by L. A. Coser) (1992) Maurice Halbwachs: On Collective Memory. Chicago: The University of Chicago Press.

Hill, M. R. (1993) Archival Strategies and Techniques. London: Sage. 
Jansen, R. S. (2007) 'Resurrection and Appropriation: Reputational Trajectories, Memory Work, and the Political Use of Historical Figures', American Journal of Sociology 112 (4): pp. 953-1007.

Jordan, J. (2006) Structures of Memory: Understanding Urban Change in Berlin and Beyond. Stanford: Stanford University Press.

Kvale, S. (1996) InterViews: An Introduction to Qualitative Research Interviewing. London: Sage.

Larson, J. and Lizardo, O. (2007) 'Generations, Identities and the Collective Memory of Che Guevara’, Sociological Forum 22 (4): pp. 425-451.

Levy, D. and Sznaider, N. (2006) The Holocaust and Memory in the Global Age. Philadelphia: Temple University Press.

Levy, D. and Sznaider, N. (2002) 'Memory Unbound: The Holocaust and the Formation of Cosmopolitan Memory’, European Journal of Social Theory 5(1): pp. 87-106.

Mazlish, B. (2005) 'The Global and the Local’, Current Sociology 53(1): pp. 93-111

Meyer, J., Boli, J., Thomas, G. M. and Ramirize, F. O. (1997) 'World Society and the Nation-State’, American Journal of Sociology 103(1): pp. 144-181.

Meyer, J. (2004) 'The nation as Babbitt: how countries conform', Contexts 3(3): pp. 4247.

Misztal, B. (2003) Theories of Social Remembering. Maidenhead: Open University Press.

Mullan, D. (2002) Eyewitness Bloody Sunday: The Truth. Dublin: Merlin Publishing.

O’Clery, C. (1996) The Greening of the White House: the inside story of how America tried to bring peace to Ireland. Dublin: Gill and Macmillan.

Olick, J. (ed.) (2003) States of Memory: Continuities, Conflicts, and Transformations in National Retrospection. Durham: Duke University Press.

Olick, J. (1999) 'Genre Memories and Memory Genres: A Dialogical Analysis of May 8, 1945 Commemorations in the Federal Republic of Germany’, American Sociological Review 64 (3): pp. 381-402.

Olick, J. K. and Robbins, J. (1998) 'Social Memory Studies: From "Collective Memory" to the Historical Sociology of Mnemonic Practices', Annual Review of Sociology 24: pp. 105-140. 
Ó Riain, S. (2006) 'Time-space intensification: Karl Polanyi, the double movement, and global informational capitalism’, Theory and Society 35(5-6): pp. 507-528.

Rappaport, J. (1990) The Politics of Memory: Native Historical Interpretation in the Colombian Andes (Cambridge: Cambridge University Press).

Robertson, R. (1992) Globalization: Social Theory and Global Culture. London: Sage.

Rolston, B. (1991) Politics and Painting: Murals and Conflict in Northern Ireland. London: Associated University Presses.

Roudometof, V. (2005) ‘Transnationalism, Cosmopolitanism and Glocalization’, Current Sociology 53(1): pp. 113-135.

Sarantakos, S. (1993) Social Research. Hampshire: The Macmillan Press.

Schudson, M. (2001) 'Lives, Laws, and Language: Commemorative versus NonCommemorative Forms of Effective Public Memory', The Communication Review2 (1): pp. 3-17.

Smith, A. D. (1990) 'Towards a Global Culture?', in M. Featherstone (ed) Global Culture: Nationalism, Globalization and Modernity. London: Sage.

Spillman, L. (2003) 'When Do Collective Memories Last? Founding Moments in the United States and Australia', in J. Olick (ed) States of Memory: Continuities, Conflicts, and Transformations in National Retrospection. Durham: Duke University Press.

Spillman, L. and Conway, B. (2007) 'Texts, Bodies, and the Memory of Bloody Sunday’, Symbolic Interaction 30 (1): pp. 79-103. 